\title{
Developing English Writing Materials in Narrative Text Based on Genre-Based Approach
}

Ismi Novitasari Sinaga ${ }^{1} \&$ Tri Fitriyani ${ }^{2}$

${ }^{1,2}$ Faculty of Cultural Sciences, Universitas Sumatera Utara

ARTICLE INFO

Article history:

Received April 2, 2019

Revised May 3, 2019

Accepted June 15, 2019

\section{Keywords:}

Developing,

Writing Materials,

Narrative Text,

Research and Development

\section{Clonflict of Interest:}

None

Funding:

None

\begin{abstract}
This study aims to develop appropriate English writing materials by using Genre-Based Approach. This study was conducted by Research and Development $(\mathrm{R} \& \mathrm{D})$ design through six stages; gathering data and information, analyzing data, designing new materials, validating by experts, revising and final product. It was conducted at SMA Negeri 14 Medan for grade XI, consisting of 32 students. Instrument for collecting data was document, questionnaire and interview. Based on the data, it found some writing material, which has inappropriate instruction related to writing a text that should be developed based on syllabus and students' needs. In analyzing students' needs, the questionnaire was distributed to 32 students and also conducting an interview to the teacher and students. Then, the researchers design the new materials that validated by experts. The results of validating show 91,6\% from English lecturer and 80\% from English teacher. It means the developing materials are categorized as "relevant" for the grade XI students at SMA Negeri 14 Medan.
\end{abstract}

Corresponding Author: Ismi Novitasari Sinaga, Faculty of Cultural Sciences, University of Sumatera Utara, Jalan Universitas No.19 Kampus USU, Kota Medan, Sumatera Utara 20155 E-mail: ismi.novita22@gmail.com.

Copyright $\left({ }^{\circ}\right.$ Association of Language Teachers in Southeast Asia. All rights reserved

\section{INTRODUCTION}

As an international language, English is used in all aspects of human life. Its main function is being a system of communication for people around the world. It is because every country has its own language. Thus, English is needed as a universal language. Knowing that importance, it seems that everyone has to be able to comprehend it because having a good ability in English will give many advantages. That is why English becomes one of compulsory subjects which is taught in Indonesia from junior high school.

English is taught at schools in order that students are able to master the four skills; they are listening, speaking, reading, and writing. Harmer (2007: 265) states that we use language in terms of four skillsreading, writing, speaking and listening. These are often divided into two types. A receptive skill is a term used for reading and listening, skills where meaning is extracted from the discourse. A productive skill is the term for speaking and writing, skills where students actually have to produce language themselves.

Among those four skills, writing is the most difficult skill to learn and to master, because writing is an active or productive skill so that students who are learning writing have to learn how to find ideas, and express them into writing.Thus, the ability in writing is needed. Writing is not simply transferring thought to a written form. It needs appropriate vocabulary, grammar, coherence, and organization. As it is stated by Nunan (1989: 36) writing is not a natural activity because people have to be taught how to write. It is clearly shown that this 
skill is more complicated than the other skills. It is being a difficulty for students to write a good writing and becomes a problem in teaching learning process.

Based on the researcher's experience in field teaching practice (PPL) at SMA Negeri 14 Medan Grade XI, It was found that there are still a lot of students who are not able to write appropriately, especially in writing Narrative text. Some problems arise when students asked to write. The first problem is the lacks of students' ability in compose a good writing. It takes big deals in teaching and learning process because it will determine the learning results. Besides, textbook which are used by teachers are not appropriate with students' needs. In the task of writing Narrative text, the students are not required to make a Narrative text but they required to read the existing passage and then divide them into paragraphs. The data as follow:

Work in groups of four. Read this passage intensively. This is a part of the text in task 1 above. Divide them into parahraphs! (Better English Language skills, Page 119, Topic: Narrative; Legend and Myth)

The data shows that the instruction is not appropriate in writing task. Thus, the students cannot compose a good narrative and cannot understand the materials given well. Then, the teachers still find some difficulties in making their own teaching materials because of some factors.

Based on the preliminary data, it can be concluded that designing innovative materials can be chosen as the solution. Brown (1994) states that teachers need to supplement materials to promote motivation, which is one of the key factors in learning. The materials should be based on students' needs.

However, teachers have to use appropriate approach in order to reach the aim of the teaching and learning process. Applying Genre-Based Approach can be the solution for improving students' skills. Hammond and Derewianka (2001) define the Genre-Based Approach as the way to language and literacy education that combines an understanding of genre and genre teaching together. This approach provides stages and strategies to help students have better understanding about appropriate writing, and it will also give some examples of texts related to the Narrative genres. It gives clear explanations of genre that will be easier to be understood by student.

\section{REVIEW OF LITERATURE}

Nunan (1989:36) states that writing is an extremely complex cognitive activity in which the writer is required to demonstrate control of variables simultaneously. Kane (2000:17) also describes that writing is a complex activity, when we think about a topic we are already beginning to select words and construct sentences or in other words to draft. These include control of content, format, sentence structure, vocabulary, punctuation, spelling, and a letter formation.

Material development is a process of developing existing materials because there are some items of the existing material which need to be added or eliminated. Teaching material development includes the process of adaptation, supplement, and elaboration of teaching materials in order to make the teaching materials fulfill what students need about a subject that they learn.

In foreign or second-language writing, a genre-based approach refers to teaching learners how to make use of language patterns to achieve a coherent, purposeful composition (Hyland, 2003). Genre-Based Approach has some stages as the cycle in the teaching and learning process. Hammond, Burns, Joyce, Brosnan, and Gerot (1992: 19-24) suggests four stages that can be applied in this approach. They are Building Knowledge of Field (BKOF), Modeling of Text (MOT), Joint Construction of a Text (JCOT), and Independent Construction of the text (ICOT).

\section{RESEARCH METHOD}

This research was conducted by using Research and Development (R \& D) which adapted from Borg and Gall (1985:775).R \& D has stages of educational research as following:

1. Gathering information and data

2. Analyzing data

3. Designing new writing materials

4. Validating new writing materials

5. Revising new writing materials

6. Developing writing materials (final products) 
The sources of data were syllabus, and existing teaching materials. Besides that, there was an observation and teachers' interview. The data were analyzed descriptively.

\subsection{Techniques of Analyzing Data}

The data of this study were students' need analysis and existing materials. The data were analyzedto get the solution of students' problem and appropriate writing material based on students' need. Later, this data used to develop new writing material. The data were analyzed through the following steps. First, Need analysis by using questionnaires and interviews was conducted. Questionnaires administered to the 32 students to get the related data. Interviews administered to the teacher to support the questionnaires, and then the data tabulated in order to obtain the best solution in preparing what materials design which were appropriate for the eleventh grade students In SMA Negeri 14 Medan. After that, the syllabus and the existing materials were analyzed. In this stage the writer considered between the basic competence as well as the book, before developing the materials.

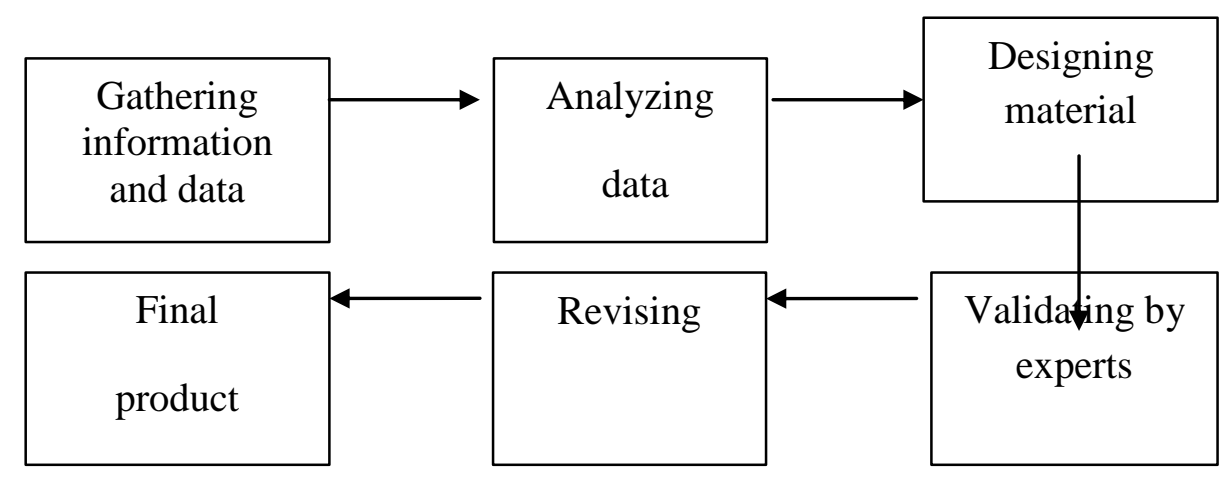

Figure 1. Diagram of Material Development

\section{Results}

\subsection{Need Analysis Results}

\subsubsection{The Description of the Target Needs}

By seeing the result of necessities, the students really needed to improve their writing skill. Besides, in relation to the students' lack, There are $50 \%$ students claim that they got difficulty on grammar. Then it followed by the difficulty on choosing vocabularies. $28,12 \%$ students claim that vocabularies also needed, because in writing a text they have to know the vocabularies and how the structure of grammar to compose a good writing. While in the terms of wants, 46,87\% of students expected can write a text in 200-300 words. It means they have great passion in learning writing. By developing appropriate Englishwriting material, it can be improve their writing skill as they expected.

\subsubsection{The Description of Learning Needs}

The students learning needs were found $31,25 \%$ choose incomplete text and jumbled paragraph. It means that teacher usually give incomplete text and jumbled paragraph as the input. Besides, input that students want is pictures and jumbled paragraph with the number $31,25 \%$. It can conclude that the students prefer inputs that interest them such as interesting picture. In the developed material, there are some materials provided related to picture and jumbled paragraph. It means that both of them are match to students' needs. In addition, the length of text in writing that usually asked by teacher is 100-200 words with the number 46,87\%.

Besides, $50 \%$ of the students state that the teacher usually gives topics related to education in teaching writing. While, $71,87 \%$ of them think that the appropriate topic in learning writing is topics that related to daily life. Most of them want the topics that related to daily life. It can conclude that the students will be easier to understand the topic that related to daily life so that they can learn writing easily then produce it well. From the result, the researcher has to know their preferred topic in learning writing. It could be considered in developing the materials in order to help the students to adjust what topic they want. 


\subsection{The result of Interview}

From the interview section, most of students cannot write appropriately, because of their lack of vocabularies, lack of grammar, and also the existing material was not appropriate with their needs. Furthermore, teacher also has obstacles in teaching writing.

\subsection{The Material Design}

The materials have been designed based on students' needs. The development of materials was Narrative text. The previous text (in Better English Language skills, Page 115, Topic: Narrative; Legend and Myth)were about Rama and Sinta.

Based on the data, The English writing material should be designed based on potency and condition of region, so students can thoroughly understand easily. Especially in Narrative text, the material should be related to stories in Sumatera Utara, it can make the students easier to understand the Narrative text. So, the researchers make a new text with the title The legend of Putri Hijau. It was the stories from Sumatera Utara.

Then, the researchers also put the stories about The Legend of Lake Toba. The students will be interested in analyzing the generic structure of text because they have known about the stories. It will build their knowledge related to generic structure gradually before doing another task.

Genre-Based is used as the approach in this developed materials which consisted of BKOF (Building Knowledge of Field), MOT (Modeling of Text), JCOT)Joint Construction of Text), and ICOT (Independent Construction of Text). The following figure describes the parts of each unit of the materials.

\begin{tabular}{|l|c|c|}
\hline \multirow{2}{*}{ Title } & BKOF & Let's Start \\
\cline { 2 - 3 } & MOT & Let's Move \\
\hline \multirow{2}{*}{ JCOT } & Finding Out \\
\cline { 2 - 3 } & ICOT Let's Creat \\
\hline
\end{tabular}

Figure 2. The Design of Material

BKOF $=$ Building Knowledge of Field

MOT = Modeling of Text

JCOT = Joint Construction of Text

ICOT = Independent Construction of Text

According to figure 4.2, the first part is BKOF. It entitles Let's Start. In this part, students will be stimulated to the materials that will be learnt. Then, it will help them to recall their present knowledge. In this task the researcher provide some picture related to Kind of Narrative text.

The second part of the materials entitles Let's Move. This part is in the stage of MOT. In this part, examples of texts are given and followed by some questions to comprehend the texts.T hen, the generic structure of the texts will be analyzed by the students. The third part is Finding Out which is in the stage of JCOT. The discussion of this part focuses on grammar and exercises. These tasks gave the students opportunities to understand more information about the simple past tense and direct-indirect speech. Then, in Task 9 there were an activity to analyze the simple past tense of the text. The researcher also provide an activity related to analyze the used of conjunction, it presented in Task 10.

The fourth part is in the stage of ICOT which entitles Let's Create. The activity in this part are arranging jumbled paragraphs, rewriting texts, and writing their own texts about Narrative text. Then, the last part is summary and reflection. It will summarize the main materials. While in reflection, students will evaluate their own success and lack in learning the materials.

\subsection{The Expert Validation}

Two experts evaluated the two materials and the following tables are the results of experts' judgment. 
SALTeL

e-ISSN: 2614-2684

92

Table 1. The Validation Result by Expert 1

\begin{tabular}{lllll}
\hline No. & Criteria & $\begin{array}{l}\text { The Number of } \\
\text { Criteria }\end{array}$ & Maximum Score & Score \\
\hline 1. & Linguistic & 7 & 35 & 32 \\
\hline 2. & Process & 5 & 25 & 22 \\
\hline 3. & Content & 7 & 35 & 33 \\
\hline 4. & Layout & 5 & 25 & 23 \\
\hline Total & 24 & 120 & 110
\end{tabular}

Average Score $=\frac{\mathbf{1 1 0}}{\mathbf{2 4}}=4,6$ or Percentage $=\frac{\mathbf{1 1 0}}{\mathbf{1 2 0}} \times 100=91,6 \%$

Table 2. The Validation Result by Expert 2

\begin{tabular}{lllll}
\hline No. & Criteria & $\begin{array}{l}\text { The Number of } \\
\text { Criteria }\end{array}$ & $\begin{array}{l}\text { Maximum } \\
\text { Score }\end{array}$ & Score \\
\hline 1. & Linguistic & 7 & 35 & 30 \\
\hline 2. & Process & 5 & 25 & 18 \\
\hline 3. & Content & 7 & 35 & 26 \\
\hline 4. & Layout & 5 & 25 & 22 \\
\hline Total & 24 & 120 & 96
\end{tabular}

Average Score $=\frac{\mathbf{9 6}}{\mathbf{2 4}}=4$ or Percentage $=\frac{\mathbf{9 6}}{\mathbf{1 2 0}} \times 100 \%=80 \%$

The average score from two experts were 4,6 and 4,0 with percentage $91,6 \%$ and $80 \%$. Based on the result, it showed that the materials, which are developed appropriate to be used by students, grade XI of SMA Negeri 14 Medan.

\section{CONCLUSION}

The students Grade XI in SMA Negeri 14 Medan were needed the English writing material which can support their learning activities. Their learning activity was supposed to increase their knowledge in writing Narrative text. Then, the writing materials on general English textbook did not approopriate with the students needs and it should be developed. The English writing material should be developed through five phases, they were; 1) gathering information and data, 2) Analyzing the data, 3) Designing materials based on the need analysis, 4) validating the new writing materials by experts (English teacher and English lecturer), 5) Revising- developing material (Final Product).

\section{REFERENCES}

Alyani, R. F. (2015). Developing Writing Materials By Using Genre-Based Approach For The First Semester Of The Tenth Grade Students At SMA Piri 1 Yogyakarta. Yogyakarta: Universitas Negeri Yogyakarta

Amelia, Z (2016). Developing English reading Material for Fashion Design Program in Vocational School. Medan: State University of Medan.

Borg, W.R and Gall, M.D (1985).Educational Reasearch An Intruduction. New York: Longman

Brown, H. D. (2000). Teaching by Principles An Interactive Approach to Language Pedagogy. San Fransisco; Longmam

BSNP. (2006). Instrumen Penilaian Buku Teks Pelajaran pada Pendidikan Dasar dan Menengah. Jakarta: Pusat penerbitan Universitas Terbuka

Callaghan, M and Rothery, J. (1988). Teaching Factual Writing: Genre-based Approach. Sydney. DSP Marketing.

Feez, S., and Joyce, H. (1998). Text-Based Syllabus Design. Sydney: Macquarie University.

Halliday, M.A.K. (2007). Language and Education. Great Britain: Biddles Ltd. 
Hammond, J., Burns, A., Joyce, H., Brosnan, D. \& Gerot., L. (1992). English forSocial Purpose: A Handbook for Teachers of Adult Literacy. Sydney: National Centre for English Language Teaching and Research.

Harmer, J. (2001). The Practice of English Language Teaching. London: Longman.

Heffernan, J. A.W. and Lincoln, J. E. (1986). Writing: A Collage Handbook. New York: Norton.

Hutchinson, T., and Waters, A. (1987). English for Specific Purpose. London: Cambridge University press.

Hyland, K. (2004). Genre and Second Language Writing. Arbor: University of Michigan Press.

Javed, M., Juan, W., and Nazli, S. (2013). A Study of Students' Assesment in Writing Skills of The English Language. International Journal of Instruction. 6(2).

Knapp, P and Watkins, M. (2005). Genre, Text, Grammar: Technologies and Assessing Writing. Sydney: University of New South Wales.

Langan, J. (2010). Exploring writing: Sentences and paragraphs (2nd ed.). NewYork: McGraw-Hill.

Maroko, M (2013). Development of language materials for national development: A language management perspective. International Journal of Education and Research. 1(7).

Moore-Hart, M. A. (2010). Teaching writing in diverse classroon. Boston: Pearson Education, Inc.

Nunan, D. (1989). Designing Tasks for the Communicative Classroom. Cambridge: Cambridge University Press.

Richards. J.C. and Renandya, W.A. (2002). Methodology in Language Teaching: An Anthology of Current Practice. Cambridge: Cambridge UniversityPress.

Richards, J.C. (2006). Communicative Language Teaching Today. New York: Cambridge University Press.

Swales, J. M. (1990). Genre Analysis English in Academic and Research Settings. Cambridge: Cambridge University Press.

Tomlinson, B. (1998). Reading in a Second Language: Process, Product, and Practice. London and New York: Longman. 